\title{
New hybondontoid shark from the Permocarboniferous (Gzhelian-Asselian) of Guardia Pisano (Sardinia, Italy)
}

Jan Fischer, Jörg W. Schneider, and Ausonio Ronchi

Acta Palaeontologica Polonica 55 (2), 2010: 241-264 doi: http://dx.doi.org/10.4202/app.2009.0019

Numerous isolated teeth, fin spine fragments and dermal denticles of a hybodont shark from a lacustrine limestone horizon at the top of lithofacies B of the Late Carboniferous to Early Permian succession of the Guardia Pisano Basin (Sulcisarea, southwestern Sardinia, Italy) are assigned to a new species of the genus Lissodus Brough, 1935. Lissodus sardiniensis sp. nov. is erected on the basis of about 500 teeth, which show a unique feature of only one pair of lateral cusps that are bent in the direction of the prominent central cusp. Weak heterodonty allows distinction of symphyseal, mesial to anterolateral, and lateral teeth. Lissodus sardiniensis sp. nov. was a freshwater-adapted durophagous shark of bottom dwelling habit, an interpretation supported by general construction of the dentition and the morphology of the dermal denticles. The association with Acanthodes, diplodoselachid sharks and branchiosaurs allows the reconstruction of a five-level trophic chain for the Guardia Pisano Basin. The discovery of Lissodus in Sardinia is presently the southernmost known occurrence of that genus in the Late Palaeozoic of Europe. This new find adds significantly to knowledge of migration routes of aquatic organisms, especially freshwater sharks, between the single European basins in the Late Pennsylvanian, and changes in palaeobiogeography during the Early Permian.

Key words: Chondrichthyes, Hybodontoidea, Lissodus, taxonomy, palaeoecology, palaeobiogeography, Sardinia, Italy.

Jan Fischer [j.fischer1@yahoo.de] and Jörg W. Schneider [schneidj@geo.tu-freiberg.de ], Department of Palaeontology, Geological Institute, Technische Universität Bergakademie Freiberg, Bernhard-von-Cotta Straße 2, 09599 Freiberg, Germany; Ausonio Ronchi [ausonio.ronchi@manhattan.unipv.it], Dipartimento di Scienze della Terra, Università di Pavia, Via Ferrata 1, 27100 Pavia, Italy.

This is an open-access article distributed under the terms of the Creative Commons 
Attribution License (for details please see creativecommons.org), which permits unrestricted use, distribution, and reproduction in any medium, provided the original author and source are credited.

Fof $\underline{\text { Full text }(1,519.1 \mathrm{kB})}$ 